\title{
Article \\ Effect of Sawdust Particle Size on Physical, Mechanical, and Energetic Properties of Pinus durangensis Briquettes
}

\author{
Christian Osvaldo Zepeda-Cepeda ${ }^{1}$, José Rodolfo Goche-Télles ${ }^{1}$, Celina Palacios-Mendoza ${ }^{1}$, \\ Oswaldo Moreno-Anguiano ${ }^{2}\left(\mathbb{D}\right.$, Víctor Daniel Núñez-Retana ${ }^{3}$, Maginot Ngangyo Heya ${ }^{4} \mathbb{D}$ and \\ Artemio Carrillo-Parra ${ }^{3, * \text { (D) }}$
}

Citation: Zepeda-Cepeda, C.O.; Goche-Télles, J.R.; Palacios-Mendoza, C.; Moreno-Anguiano, O.;

Núñez-Retana, V.D.; Heya, M.N.; Carrillo-Parra, A. Effect of Sawdust Particle Size on Physical, Mechanical, and Energetic Properties of Pinus durangensis Briquettes. Appl. Sci. 2021, 11, 3805. https://doi.org/ 10.3390/app11093805

Academic Editor:

Borja Velazquez-Marti

Received: 20 March 2021

Accepted: 9 April 2021

Published: 23 April 2021

Publisher's Note: MDPI stays neutral with regard to jurisdictional claims in published maps and institutional affiliations.

Copyright: (c) 2021 by the authors. Licensee MDPI, Basel, Switzerland. This article is an open access article distributed under the terms and conditions of the Creative Commons Attribution (CC BY) license (https:// creativecommons.org/licenses/by/ $4.0 /)$.
1 Forestry Faculty (FF), Juarez University of the State of Durango (UJED), Río Papaloapan and Blvd. Durango S/N Col. Valle del Sur, Durango 34120, Mexico; cf_esvaldo@outlook.es (C.O.Z.-C.); jgoche@ujed.mx (J.R.G.-T.); celina.palacios@ujed.mx (C.P.-M.)

2 Institutional Doctoral Program in Agricultural and Forestry Sciences (PIDCAF), Juarez University of the State of Durango (UJED), Río Papaloapan and Blvd. Durango S/N Col. Valle del Sur, Durango 34120, Mexico; oswaldo.moreno@ujed.mx

3 Institute of Silviculture and Wood Industry (ISIMA), Juarez University of the State of Durango (UJED), Boulevard del Guadiana 501, Ciudad Universitaria, Torre de Investigación, Durango 34120, Mexico; daniel_mzp@hotmail.com

4 Faculty of Agronomy (FA), Autonomous University of Nuevo León (UANL), Francisco Villa s/n, Col. Ex-Hacienda "El Canadá", Escobedo 66050, Nuevo León, Mexico; nheyamaginot@yahoo.fr

* Correspondence: acarrilloparra@ujed.mx; Tel.: +52-61-8180-9912

Abstract: Particle size is a physical property that sometimes limits the quality of briquettes, so it is recommended to use different sizes in mixtures for their manufacture. The objective of this research was to evaluate the effect of different particle sizes of sawdust in mixtures on some physical, mechanical, and energetic properties of briquettes made from Pinus durangensis sawdust, as well as set the ranges within the appropriate values found to obtain desired values. Three particle sizes were established (large, medium, and small), and 10 mixtures were prepared using different percentages of each particle classification. The particle density, volumetric swelling, compressive strength, impact resistance index (IRI), and gross calorific value of the briquettes were evaluated. For the determination of optimal mixtures, the surface response methodology was used under a three-factor simplex-lattice model. The particle density values were in the range 0.92 to $1.02 \mathrm{~g} \mathrm{~cm}^{-3}$ and the volumetric swelling was 0.96 to $3.9 \%$. The highest resistance to compression was $37.01 \mathrm{~N}$ $\mathrm{mm}^{-1}$, and the IRI was found in the range of 53 to $107 \%$. The gross calorific values were from 19.35 to $21.63 \mathrm{MJ} \mathrm{kg}^{-1}$. The selection of different particle sizes for the mixtures increases the quality of the briquettes.

Keywords: bioenergy; biomass; briquettes; particle size; pine sawdust; surface response methodology; contour graphics

\section{Introduction}

Sawdust and other by-products generated in forest industries are often considered a problem in work areas and woodlands, since disposal can create wildfires during periods of intense heat, generating dust in the air, and block areas in production facilities $[1,2]$. Regarding biomass availability, the genus Pinus in Mexico represents the most important forest resource, reaching 5.0 million $\mathrm{m}^{3}$ year $^{-1}$ of rolled wood in the last decade [3]. Much of the waste produced by the forest industry comes from the harvesting of coniferous forests and pine species [1]. Villela-Suárez et al. [4] estimated that around 31,000 $\mathrm{Mg} \mathrm{year}^{-1}$ of forest residues from the genus Pinus are generated in the region of El Salto, Mexico; this volume could generate energy of approximately $65.6 \mathrm{GW}$ h year ${ }^{-1}$. For comparison, Cruz-Contreras [5] and Nájera-Luna et al. [6] calculated that $43.7 \pm 5 \%$ of residual biomass in the state of Durango comes from a forest industry, of which $7.95 \%$ corresponded to 
sawdust from conifers. These aforementioned by-products may appear in the form of sawdust, bark, or chips, and are considered biomass with ideal potential for thermal energy production through briquette densification with applications in generators of steam, boilers, and turbines [7].

Briquettes are solid biofuels made with or without additives from biomass densification, and with specific properties derived from the proportion of material/additive, pressure, temperature, and time utilized in their manufacture as well as the typical physicochemical properties of biomass [8]. The production of briquettes promotes the cleanliness and care of the environment because they are made from waste, and expanded production promotes local economic development, reducing energy dependence on fossil fuels [9].

The particle size of sawdust from which briquettes are manufactured significantly affects their physical and mechanical properties as well as combustion characteristics [10]. Additionally, processing parameters such as moisture content of the sawdust, pressing temperature, and compacting pressure are factors that have a significant impact on briquette quality and strength. Generally, briquettes with lower moisture content are of lower quality. However, it has been determined in some studies that excessively low moisture content degrades the mechanical properties of briquettes [11]. According to Kers et al. [12] briquettes manufactured at lower pressures (30 to $60 \mathrm{MPa}$ ) fall to pieces easily, but at higher pressures (150 to $250 \mathrm{MPa}$ ), are consistent and compact. Additionally, increasing the compaction temperature causes plasticizing of the particles and activation of natural binders in the material, increasing the strength of the briquettes [13]. For this reason, making briquettes with the right proportion of different particle sizes is important, because briquettes obtained with irregular particle sizes and shapes suffer some disadvantages [14]. Consequently, it is recommended to use sawdust mixtures with different proportions of particle sizes and evaluate their biomass characteristics in terms of physical, mechanical, and energy properties to produce briquettes with consistent physical properties (size, shape, and density) that facilitate the feeding of furnaces and boilers [15].

The response surface methodology (RSM) is one of the methodologies used to thoroughly assess the effect of particle size on other physical-mechanical and energetic properties of solid biofuels. This methodology consists of a set of mathematical and statistical procedures that analyze the phenomena or experiments in which one or more variables are influenced by others [16]. Thus, it is known as the response surface to the relationship between variable response and factor levels in an experiment. The difference between RSM and a factorial experimental design is that an experimental design aims to locate the "winner" treatment among all those that have been tested. Instead, RSM aims to identify the conditions that result in optimal values for one or more product quality characteristics [17].

Several works have evaluated the quality of briquettes made from pine sawdust using this methodology, such as Niño et al. [18], who studied the influence on the mechanical properties of briquettes made from mixtures of rice husk and pine sawdust, considering the temperature, compaction time, and proportion of rice husk in the mixtures. In addition, Tumuluru et al. [19], in order to investigate the effects of process variables on density and durability, used response surface models to evaluate the impact of the process conditions on wheat, oat, barley, and canola straw briquettes and designed experiments at three levels of compression pressure, die temperature, feedstock moisture content, and hammer mill screen size. In other research, Križan et al. [20] studied the interaction of compaction pressure and pressing temperature on the density of briquettes made of pine and oak with different particle sizes and moisture content. Lela et al. [21] studied the influence of compaction pressure, material ratio, and drying temperature on the calorific power of briquettes made of cardboard sawdust. To identify the best manufacturing process for Pinus rigida briquette, Liu et al. [22] designed a multi-factor response surface experiment that considered briquette density, temperature, moisture content, particle diameter, and pressure.

Other works have also evaluated the different properties of briquettes made from other types of biomass $[9,13,23-26]$. Thus, the objectives of this study were to determine 
the effect of different particle sizes of Pinus durangensis sawdust mixtures on several physical, mechanical, and energetic properties of briquettes as well as establish the ranges of appropriate values to obtain desired values.

\section{Materials and Methods}

2.1. Timber Collection, Conditioning, and Determination of Sawdust Granulometric Distribution

Commercial logs of Pinus durangensis were collected in the cutting area of the Pueblo Nuevo forest community in the municipality of Pueblo Nuevo, Durango, Mexico. The logs were then transported to the Aserradero y Fábrica de Cajas Quintana sawmill located at Carretera Durango-Mazatlán km 98, El Salto Pueblo Nuevo, Durango, to produce lumber. When the logs were processed, $40 \mathrm{~kg}$ of sawdust residues were obtained, and the moisture content was reduced by up to $10 \%$ according to Ortiz [27]. The granulometric distribution of the sawdust was evaluated according to the UNE-EN 17827-2 standard [28]. A total of $300 \mathrm{~g}$ of material was passed through an AS 200 Basic vibratory sieve shaker for $10 \mathrm{~min}$, and the retained fractions of particles in each sieve were collected and their percentages determined. This procedure was done in triplicate. Particles sawdust percentages and distribution are shown in Figure 1.

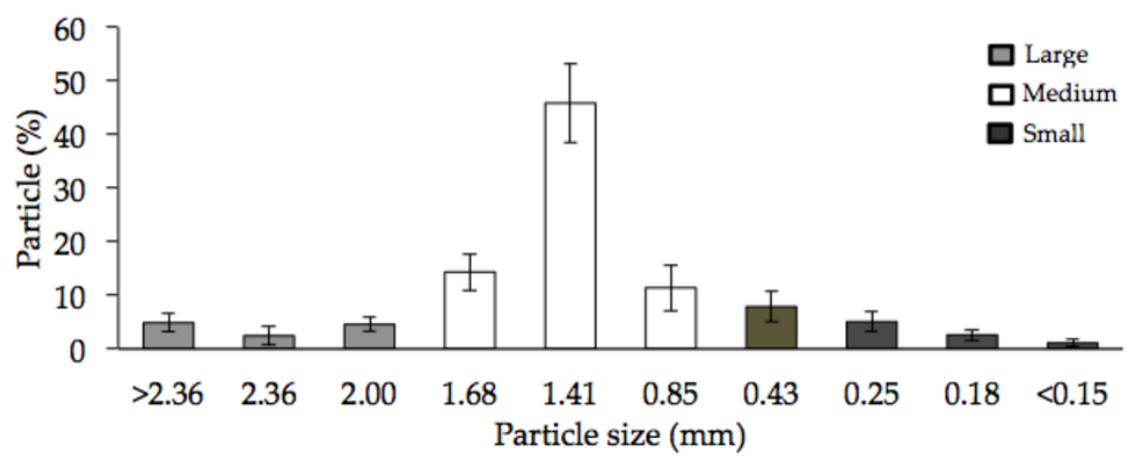

Figure 1. Particle sawdust distribution and size classification.

\subsection{Treatment, Preparation, and Conditioning of Briquettes}

The particles were classified according to size as large ( $>1.68 \mathrm{~mm})$, medium (0.59 to $1.68 \mathrm{~mm})$, or small $(<0.59 \mathrm{~mm})$, as shown in Figure 2, and 10 mixtures were prepared using different percentages of each particle classification (Table 1).

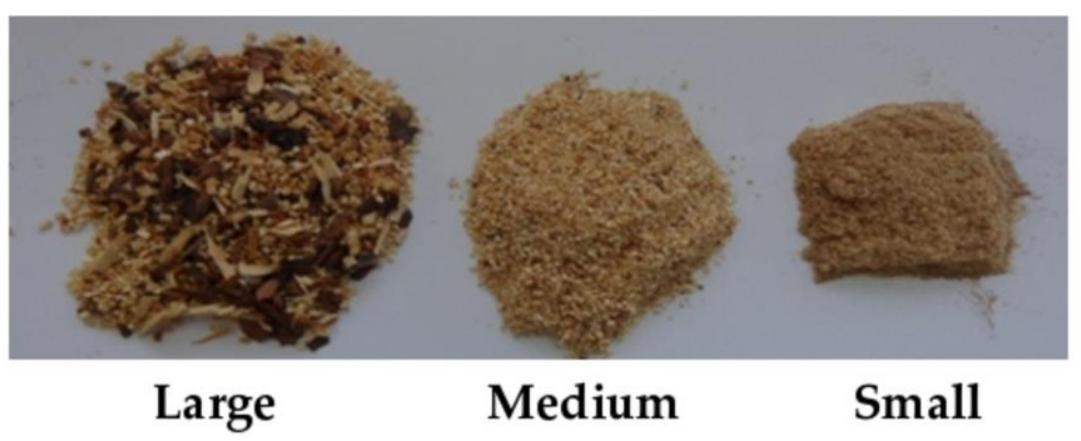

Figure 2. Size classes of Pinus durangensis sawdust particles used in mixtures. 
Table 1. Percentage of each sawdust particle size used in each treatment.

\begin{tabular}{cccc}
\hline \multirow{2}{*}{ Treatment with Sample } & \multicolumn{3}{c}{ Sawdust Size } \\
\cline { 2 - 4 } & Large (\%) & Medium (\%) & Small (\%) \\
\hline T0 & 12 & 71 & 17 \\
T1 & 100 & 0 & 0 \\
T2 & 0 & 100 & 0 \\
T3 & 0 & 0 & 100 \\
T4 & 33 & 33 & 33 \\
T5 & 67 & 33 & 0 \\
T6 & 67 & 0 & 33 \\
T7 & 0 & 67 & 33 \\
T8 & 0 & 33 & 67 \\
T9 & 33 & 67 & 0 \\
T10 & 33 & 0 & 67 \\
\hline
\end{tabular}

Ten briquettes of each treatment were produced using $40 \mathrm{~g}$ of sawdust introduced into a LIPPEL laboratory briquette producer and pressurized at $20 \mathrm{Mpa}$ for $5 \mathrm{~min}$ and $80^{\circ} \mathrm{C}$. Physical and chemical properties of the briquettes are presented in Table 2.

Table 2. Physical and chemical properties of briquettes from each treatment.

\begin{tabular}{cccccccc}
\hline \multirow{2}{*}{$\begin{array}{c}\text { Treatment } \\
\text { with Sample }\end{array}$} & \multicolumn{3}{c}{ Physical Properties (Size) } & \multicolumn{3}{c}{ Proximate Analysis Values } \\
\cline { 2 - 7 } & Weight (g) & $\begin{array}{c}\text { Diameter } \\
\mathbf{( m m )}\end{array}$ & Length (mm) & $\begin{array}{c}\text { Moisture } \\
\text { Content (\%) }\end{array}$ & $\begin{array}{c}\text { Volatile } \\
\text { Material (\%) }\end{array}$ & $\begin{array}{c}\text { Ash (\%) } \\
\text { Carbon (\%) }\end{array}$ \\
\hline T0 & $39.79(0.08)$ & $33.23(0.08)$ & $46.06(0.34)$ & $5.12(0.01)$ & $82.86(0.01)$ & $0.56(0.02)$ & $11.46(0.01)$ \\
T1 & $39.5(0.21)$ & $33.46(0.11)$ & $48.78(0.50)$ & $5.78(0.04)$ & $79.14(0.40)$ & $1.22(0.15)$ & $13.87(0.28)$ \\
T2 & $40.17(0.78)$ & $33.37(0.14)$ & $46.48(0.55)$ & $6.56(0.11)$ & $81.57(0.20)$ & $0.73(0.05)$ & $11.14(0.07)$ \\
T3 & $39.92(0.06)$ & $33.05(0.05)$ & $45.97(0.36)$ & $5.21(0.06)$ & $83.40(0.13)$ & $0.36(0.02)$ & $11.03(0.20)$ \\
T4 & $39.67(0.13)$ & $33.15(0.08)$ & $46.52(0.34)$ & $5.69(0.03)$ & $81.91(0.36)$ & $0.91(0.04)$ & $11.48(0.37)$ \\
T5 & $39.17(0.09)$ & $33.25(0.09)$ & $46.93(0.46)$ & $5.41(0.07)$ & $81.95(0.22)$ & $0.73(0.04)$ & $11.91(0.27)$ \\
T6 & $39.29(0.07)$ & $33.23(0.11)$ & $46.18(0.31)$ & $6.27(0.05)$ & $82.97(0.12)$ & $0.47(0.04)$ & $10.29(0.12)$ \\
T7 & $39.76(0.15)$ & $33.15(0.05)$ & $47.28(0.31)$ & $6.62(0.02)$ & $81.07(0.04)$ & $1.11(0.07)$ & $11.20(0.02)$ \\
T8 & $39.76(0.10)$ & $33.13(0.08)$ & $47.21(0.22)$ & $5.81(0.01)$ & $83.05(0.11)$ & $0.55(0.04)$ & $10.60(0.16)$ \\
T9 & $39.23(0.10)$ & $33.28(0.10)$ & $47.11(0.42)$ & $6.52(0.03)$ & $82.01(0.03)$ & $0.90(0.03)$ & $10.57(0.02)$ \\
T10 & $39.33(0.11)$ & $33.25(0.11)$ & $48.25(0.41)$ & $6.01(0.13)$ & $82.51(0.16)$ & $0.44(0.01)$ & $11.04(0.26)$ \\
\hline
\end{tabular}

\subsection{Determination of Briquette Quality}

Particle density was calculated immediately after briquette production and 7 days later, after reaching hygroscopic balance in a conditioning room at $20^{\circ} \mathrm{C}$ and $60 \%$ relative humidity. For the above, the briquettes were weighed and measured (diameter and length) with a digital caliper; the particle density calculation consisted of dividing the total weight of the briquette by its volume.

Using particle density data from the briquettes immediately after manufacture and after conditioning, we calculated the volumetric swelling (\%) of the briquettes with Equation (1) [29]:

$$
E X P=\left[\left(\mathrm{Vol}_{2}-\mathrm{Vol}_{1}\right) / \mathrm{Vol}_{1}\right] \times 100
$$

where EXP is the volumetric swelling of briquettes (\%), $V \mathrm{Vl}_{1}$ is the volume of the briquette immediately after manufacture $\left(\mathrm{cm}^{3}\right)$, and $\mathrm{Vol}_{2}$ is the volume of the briquette 7 days after manufacture $\left(\mathrm{cm}^{3}\right)$.

Compression resistance was obtained by applying a load perpendicular to the briquette shaft with an Instron $300 \mathrm{DX}$ universal machine following the procedure established by Borowski and Hycnar [30] and the standard ASTM D 143-83 [31]. For this test, briquettes remained in the conditioning room until the time of the test (7 days). Briquettes were measured for length at 3 points, then placed horizontally on the bottom steel plate of the 
universal machine. A compression load was applied at a constant speed of $0.305 \mathrm{~mm} \mathrm{~min}^{-1}$, and this compression force (maximum load point, $\mathrm{N}$ ) was registered at the time of rupture of the briquette. Five briquettes from each treatment were tested and the compression resistance $\left(\mathrm{N} \mathrm{mm}^{-1}\right)$ was obtained with Equation (2):

$$
C=(3 \times F) /\left(L_{1}+L_{2}+L_{3}\right)
$$

where $C$ is the compression resistance $\left(\mathrm{N} \mathrm{mm}^{-1}\right), 3$ is a constant, $F$ is the force at the fracture point $(\mathrm{N})$, and $L_{1}, L_{2}$, and $L_{3}$ are the respective lengths of the briquette measured at 3 points.

The impact resistance index (IRI) was calculated using the methodology described in ASTM D440-86 [32], where each briquette is vertically oriented and dropped twice from a height of $2 \mathrm{~m}$. The number of pieces in which it fragmented was registered. Finally, the impact resistance index was calculated as described by Richards [33] with Equation (3):

$$
I R I=(100 \times N) / n
$$

where IRI is the impact resistance index, $N$ is the number of drops (2), and $n$ is the number of fragments after $N$ drops.

Gross calorific value was measured using a LECO AE 600 calorimetric pump in accordance with the procedure set out in UNE-EN 14918 [34]. This procedure consisted of burning the sample under high oxygen pressure in a LECO AC 600 calorimetric pump. The tests were performed in triplicate on anhydrous samples and the calculations were performed automatically by the calorimeter.

\subsection{Statistical Analysis}

The normality of the data was established by the Kolmogorov-Smirnov, Lilliefors, and Shapiro-Wilk tests. Analysis of variance was applied to determine differences among treatments when data were normally distributed, and Kruskal-Wallis tests were applied for non-normally distributed data. In cases where significant statistical differences $(p \leq 0.05)$ were found, Tukey and Kruskal-Wallis tests were applied. Statistical analyses of variables were performed with R Studio ${ }^{\circledR}$.

\subsection{Determination of Optimal Mixes}

The response surface methodology (RSM) was applied to set the percentage of each type of particle that optimized the response variable values. The Statgraphics ${ }^{\circledR}$ software was used to study the effects of the components (type of particle) of the mixture on the response variables.

A three-factor simplex-lattice model was applied, where $q=3$ (particle type) and $\mathrm{m}=3$ (percentage of sawdust type), and the values that components can take are $\mathrm{xi}=0$, $1 / 3,2 / 3$, or 1 . The mixtures of three components that are formed with these values are $\left(\mathrm{x}_{1}\right.$, $\left.\mathrm{x}_{2}, \mathrm{x}_{3}\right)=(1,0,0) ;(0,1,0) ;(0,0,1) ;(2 / 3,1 / 3,0) ;(2 / 3,0,1 / 3) ;(0,2 / 3,1 / 3) ;(1 / 3,2 / 3,0)$; $(1 / 3,0,2 / 3) ;(0,1 / 3,2 / 3)$; and $(1 / 3,1 / 3,1 / 3)$. The graphical representation of this design is shown in Figure 3. These graphics are a visualization of the three-dimensional shape of the response surface, from contour lines, which serve as constant values of the response variable relative to the levels of the factors represented by an equilateral triangle, where the three vertices correspond to pure mixtures (formed by a single component), the three sides or edges represent binary mixtures that have only two of the three components, and the inner points of the triangle represent ternary mixtures in which the three ingredients are different from zero [17]. 


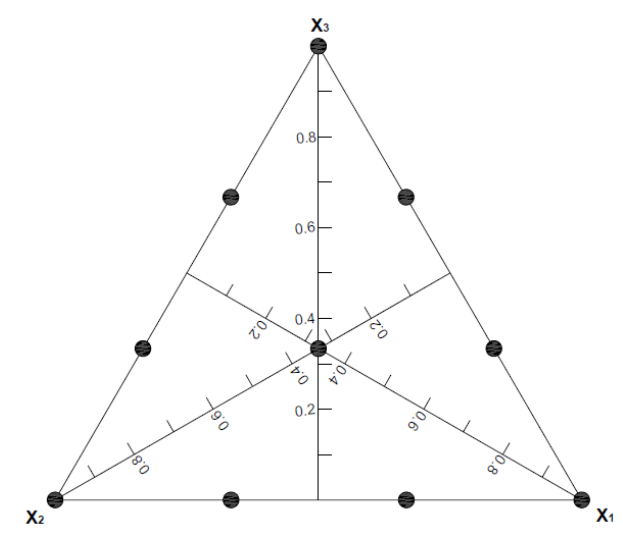

Figure 3. Simplex reticular design $(3,3)$ (Elaborated from Gutierrez and de la Vara [17]).

\section{Results}

\subsection{Physical Properties}

The particle density of the briquettes showed statistically significant differences $(p \leq 0.05)$ among treatments (Table 3$)$. The Kruskal-Wallis test $(p<0.05)$ presented four statistically homogeneous groups, with T3 (0:0:100) constituting the first; this was different from all treatments and had the highest particle density $\left(1.02 \mathrm{~g} \mathrm{~cm}^{-3}\right)$. Values ranged from 0.9 to $1.0 \mathrm{~g} / \mathrm{cm}^{3}$ with T0 (12:71:17), which showed no differences with T4 (33:33:33), but also with neither T2 (0:100:0) nor T6 (67:0:33). T7 (0:67:33), T8 (0:33:67), T6 (67:0:33), T4 (33:33:33), and T2 (0:100:0) were all in statistical group two. Group three included T9 (33:67:0) and T5 (67:33:00). The treatments with the lowest density and grouped into statistical group four were T1 (100:0:0) $\left(0.92 \mathrm{~g} / \mathrm{cm}^{3}\right)$ and T10 (33:0:67).

Table 3. Means and standard deviations of physical, mechanical, and energy properties of briquettes produced with different percentages of sawdust particle sizes.

\begin{tabular}{|c|c|c|c|c|c|c|c|c|c|c|c|c|c|c|c|}
\hline \multirow{3}{*}{$\begin{array}{c}\begin{array}{c}\text { Treatment } \\
\text { (Mixture) }\end{array} \\
\text { T0 (12-71-17) }\end{array}$} & \multicolumn{3}{|c|}{$\begin{array}{l}\text { Particle Density } \\
\qquad\left(\mathrm{g} \mathrm{cm}^{-3}\right)\end{array}$} & \multicolumn{3}{|c|}{$\begin{array}{c}\text { Volumetric Swelling } \\
(\%)\end{array}$} & \multicolumn{3}{|c|}{$\begin{array}{c}\text { Compression } \\
\text { Resistance }\left(\mathrm{N} \mathrm{mm}^{-2}\right)\end{array}$} & \multicolumn{3}{|c|}{$\begin{array}{c}\text { Impact Resistance } \\
\text { Index }(\%)\end{array}$} & \multicolumn{3}{|c|}{$\begin{array}{c}\text { Gross Calorific Value } \\
\left(\mathrm{MJ} \mathrm{kg}^{-1}\right)\end{array}$} \\
\hline & \multirow{2}{*}{$\begin{array}{c}\text { Mean } \\
1.00\end{array}$} & \multicolumn{2}{|c|}{ Std. } & \multirow{2}{*}{$\begin{array}{c}\text { Mean } \\
1.86\end{array}$} & \multicolumn{2}{|c|}{ Std. } & \multirow{2}{*}{$\begin{array}{l}\text { Mean } \\
29.06\end{array}$} & \multicolumn{2}{|c|}{ Std. } & \multirow{2}{*}{$\begin{array}{c}\text { Mean } \\
76.67\end{array}$} & \multicolumn{2}{|c|}{ Std. } & \multirow{2}{*}{$\begin{array}{c}\text { Mean } \\
19.93\end{array}$} & \multicolumn{2}{|c|}{ Std. } \\
\hline & & 0.01 & $b^{*}$ & & 0.78 & $\mathrm{~b}$ & & 1.63 & $\mathrm{bc}$ & & 20.00 & $\mathrm{ab}$ & & 0.26 & c \\
\hline $\mathrm{T} 1(100-0-0)$ & 0.92 & 0.01 & $\mathrm{f}$ & 2.01 & 1.49 & $\mathrm{~b}$ & 18.45 & 1.05 & $\mathrm{e}$ & 53.33 & 6.67 & $\mathrm{c}$ & 21.63 & 0.13 & a \\
\hline T2 (0-100-0) & 0.99 & 0.02 & c & 3.75 & 1.17 & $\mathrm{a}$ & 26.13 & 3.61 & bcd & 100.00 & 51.64 & a & 20.11 & 0.04 & bc \\
\hline T3 (0-0-100) & 1.01 & 0.01 & a & 3.00 & 0.45 & a & 37.09 & 2.51 & $\mathrm{a}$ & 99.73 & 0.37 & a & 19.48 & 0.15 & $\mathrm{~d}$ \\
\hline T4 (33-33-33) & 0.99 & 0.01 & $\mathrm{bc}$ & 1.63 & 0.99 & $\mathrm{bc}$ & 28.06 & 2.79 & bcd & 93.33 & 13.33 & a & 19.53 & 0.09 & $\mathrm{~d}$ \\
\hline T5 (67-33-0) & 0.96 & 0.01 & e & 0.96 & 0.61 & $\mathrm{c}$ & 24.53 & 2.89 & bcd & 60.00 & 8.16 & bc & 20.51 & 0.32 & $\mathrm{abc}$ \\
\hline T6 (67-0-33) & 0.98 & 0.01 & $\mathrm{~cd}$ & 1.57 & 0.86 & $\mathrm{bc}$ & 29.24 & 1.88 & $\mathrm{bc}$ & 76.67 & 20.00 & $a, b$ & 19.44 & 0.22 & $\mathrm{~d}$ \\
\hline T7 (0-67-33) & 0.97 & 0.01 & $\mathrm{~d}$ & 3.95 & 1.21 & $\mathrm{a}$ & 23.35 & 1.31 & cde & 106.67 & 48.99 & a & 19.82 & 0.04 & c \\
\hline T8 (0-33-67) & 0.98 & 0.01 & $\mathrm{~d}$ & 3.45 & 0.75 & a & 25.66 & 2.57 & bcd & 86.67 & 16.33 & a & 19.35 & 0.18 & d \\
\hline T9 (33-67-0) & 0.96 & 0.01 & $\mathrm{e}$ & 1.77 & 1.07 & $\mathrm{bc}$ & 22.71 & 3.33 & de & 93.33 & 56.37 & a & 20.99 & 0.13 & $\mathrm{ab}$ \\
\hline T10 (33-0-67) & 0.94 & 0.01 & $\mathrm{f}$ & 2.99 & 1.18 & a & 23.48 & 1.06 & cde & 73.33 & 13.33 & $a b c$ & 19.54 & 0.10 & $\mathrm{~d}$ \\
\hline
\end{tabular}

* Different lowercase letters on a column indicate statistically significant differences among treatments based on the Tukey or Kruskal-Wallis tests $(p<0.05)$.

Volumetric swelling of briquettes showed significant statistical differences $(p \leq 0.05)$ among treatments (Table 3$)$. The Kruskal-Wallis test $(p<0.05)$ presented two statistically homogeneous groups. The first group was formed by treatment T7 (0:67:33) $(3.9 \%)$ with the highest volumetric swelling, which registered no statistically significant differences $(p>0.05)$ with T2 (0:100:0), T3 (0:0:100), T8 (0:33:67), or T10 (33:0:67). In contrast, treatment T5 (67:33:0) showed the lowest volumetric swelling (1\%), followed by T6 (67:0:33) and T4 (33:33:33), with $1.6 \%$. These were all grouped into statistical group two because there were no significant statistical differences $(p>0.05)$ among them. 


\subsection{Mechanical Properties}

Resistance to compression of briquettes showed statistically significant differences among treatments $(p \leq 0.05)$ (Table 3). T3 (0:0:100) registered the highest value (37.01 N $\left.\mathrm{mm}^{-1}\right)$ and T1 (100:0:0) the lowest $\left(18.5 \mathrm{~N} \mathrm{~mm}^{-1}\right)$. On the other hand, T2 (0:100:0) had a value close to T1 (100:0:0). Additionally, significant statistical differences $(p \leq 0.05)$ were observed with T3 (0:0:100) (statistical group one) compared to the rest of the treatments (statistical group two), while T0 (12:71:17) showed no differences with T2 (0:0:100), T4 (33:33:33), T5 (67:33:0), or T8 (0:33:67).

The impact resistance index showed significant statistical differences $(p \leq 0.05)$ among treatments (Table 3). T7 (67:33:0) showed the highest value (107), while the lowest was presented by T1 (100:0:0) (53). However, T7 (0:67:33), with the highest value, was different from T1 (100:0:0), T5 (67:33:0), and T10 (33:0:67).

\subsection{Energy Properties}

Gross calorific value of briquettes presented significant statistical differences among treatments $(p \leq 0.05)$ (Table 3). The values ranged from 19 to $22 \mathrm{MJ} \mathrm{kg}^{-1}$, with the highest value registered by T1 (100:0:0), with 100\% large-particle briquettes. The first statistical group was formed by T9 (33:67:0), T5 (67:33:0), T2 (0:0:100), T0 (12-71-17), and T7 (0:67:33), whereas the second statistical group comprised the rest of the treatments, which had higher percentages of large and medium particles.

\subsection{Determination of Optimal Mixes}

The following figures show the experimental region for $\mathrm{q}=3$ components, where the region is formed by the plane that satisfies the relationship $X_{1}+X_{2}+X_{3}=1$. The response surface and contour graphs for particle density of briquettes are shown in Figure 4 . The maximum density is reached when the particle size is small, at $100 \%$. However, optimal values for making briquettes with particle densities higher than $0.98 \mathrm{~g} \mathrm{~cm}^{-3}$ were also reached when the percentage of large particles is in the range from $40-60 \%$, medium particles in the range from $10-40 \%$, and small particles in the range from $10-50 \%$.

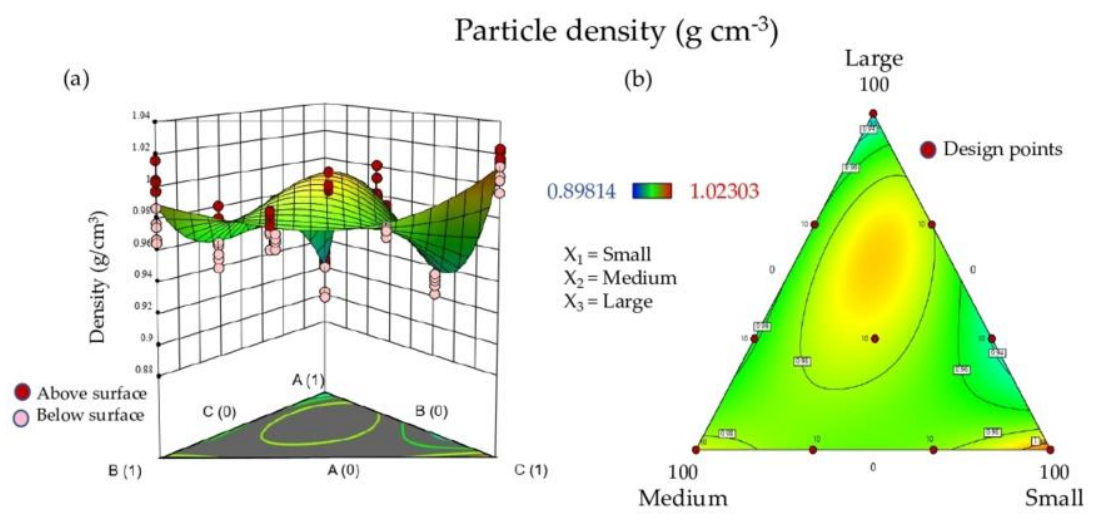

Figure 4. Response surface graph (a) and contour graph (b) of particle density from briquettes produced with different percentages of sawdust particle sizes.

The response surface and contour graphs for the volumetric swelling of the briquettes are shown in Figure 5. The lowest volumetric swelling is achieved using mixtures with a percentage of large particles in a range from $60-70 \%$, medium particles in a range from $30-50 \%$, and fine particles between 0 and $10 \%$.

The response surface and contour graphs for compression resistance of the briquettes are shown in Figure 6. The maximum compression resistance of briquettes $\left(34 \mathrm{~N} \mathrm{~mm}^{-1}\right)$ is reached when the percentage of small particles approaches 100\% (Figure 6). 


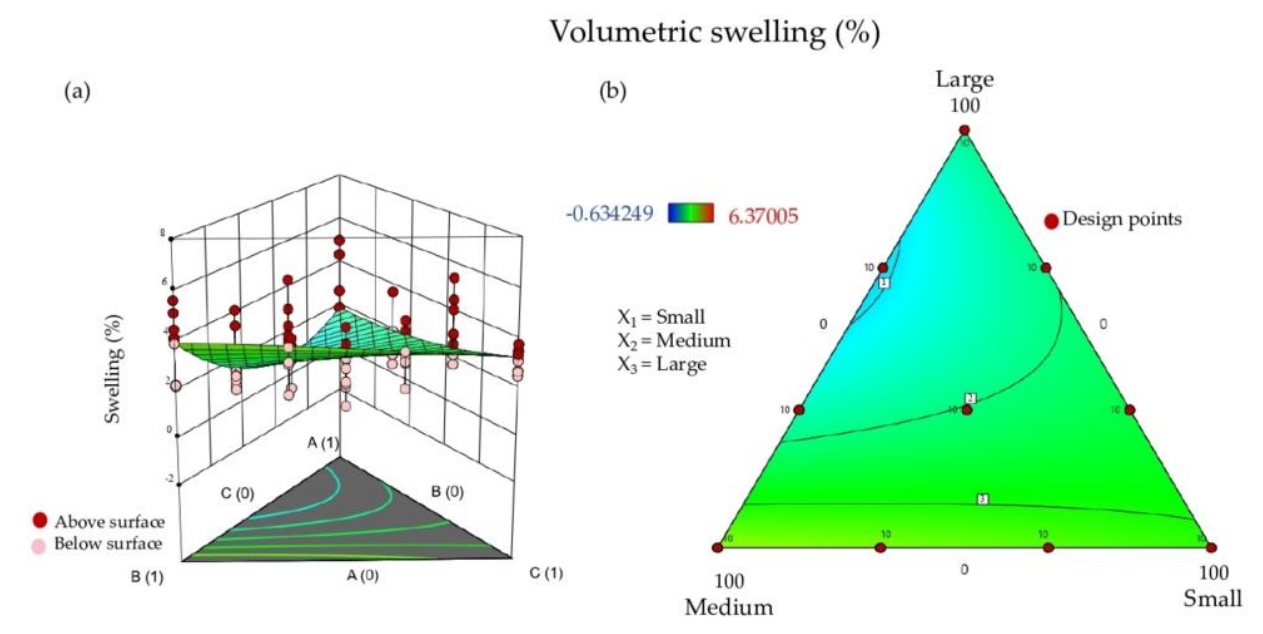

Figure 5. Response surface graph (a) and contour graph (b) of volumetric swelling from briquettes produced with different percentages of sawdust particle sizes.

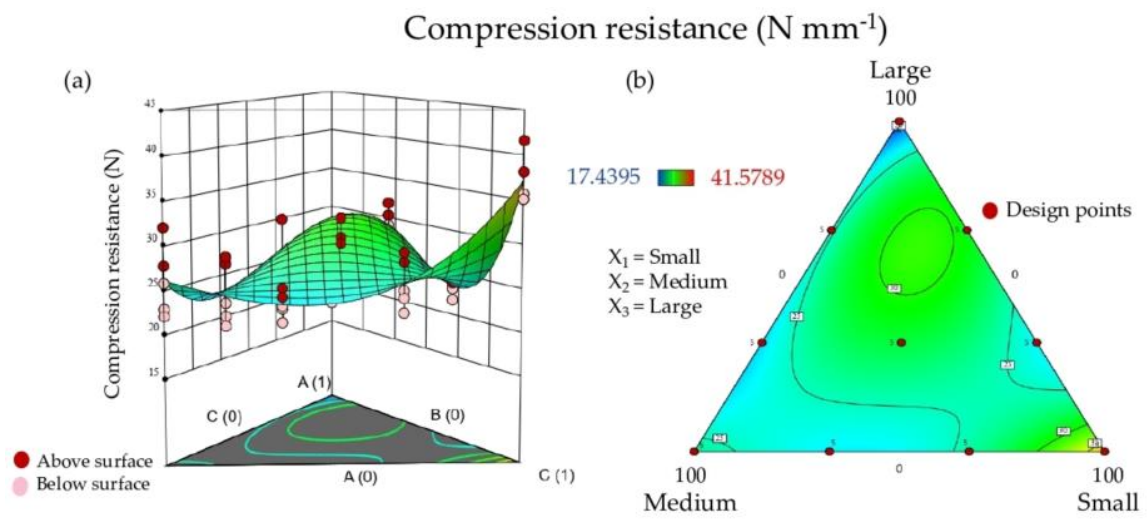

Figure 6. Response surface graph (a) and contour graph (b) of compression resistance from briquettes produced at with different percentages of sawdust particle sizes.

The response surface and contour graphs for the impact resistance index of the briquettes are shown in Figure 7. It is relevant that the maximum resistance index is obtained in mixtures with percentages of large and small particles ranging from $0-5 \%$, and medium particles from $95-100 \%$.

\section{Impact resistance index}
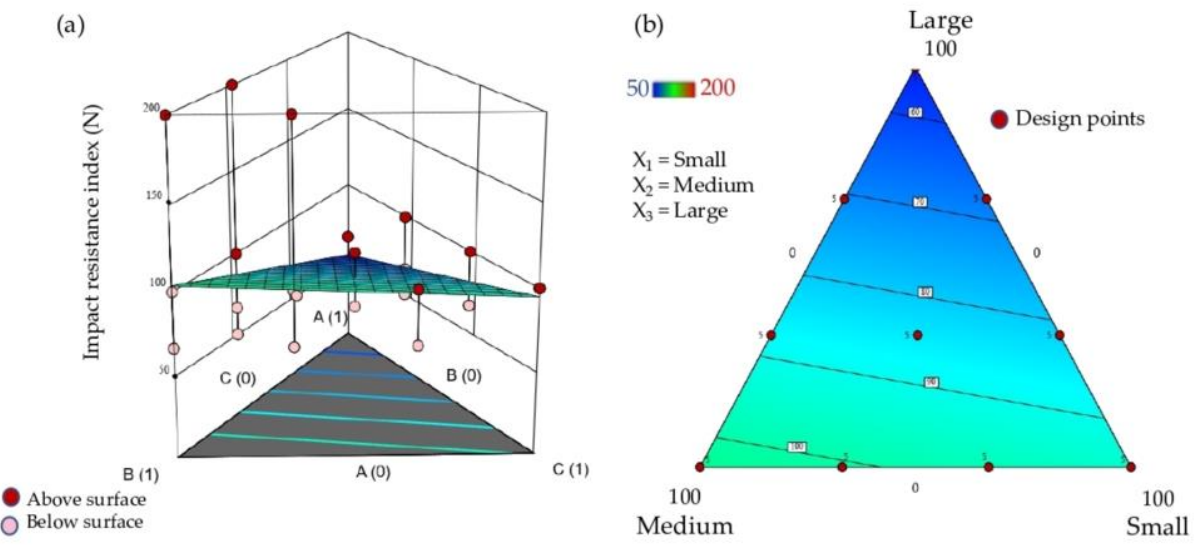

Figure 7. Response surface graph (a) and contour graph (b) of impact resistance index from briquettes produced with different percentages of sawdust particle sizes. 
The response surface and contour graphs for gross calorific value of the briquettes are shown in Figure 8. It is noted that the highest gross calorific value is reached when the percentage of large particles approaches $100 \%$. However, other mixtures allow reaching values close to the maximum. In this case, the best mixture is found using the percentage ranges of $30-35 \%$ for large particles, $65-70 \%$ for medium particles, and $0-5 \%$ for small particles.

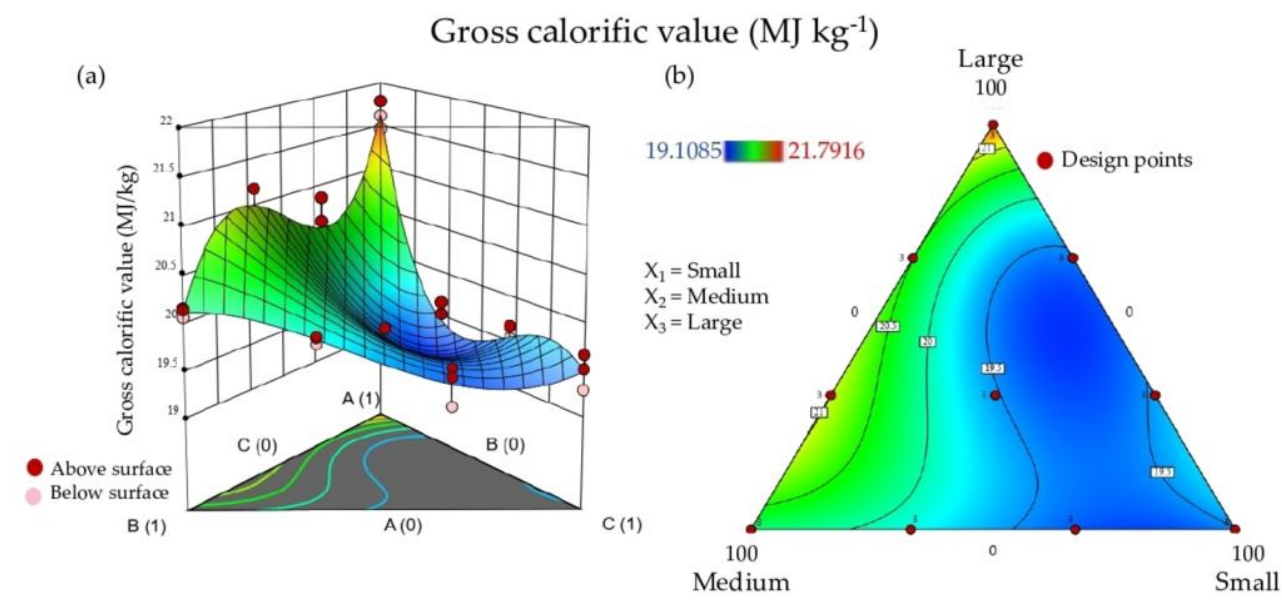

Figure 8. Response surface graph (a) and contour graph (b) of gross calorific value from briquettes produced with different percentages of sawdust particle sizes.

\section{Discussion}

\subsection{Particle Density}

The particle density of briquettes of all mixtures ranged from 0.92 to $1.01 \mathrm{~g} \mathrm{~cm}^{-3}$, meeting the standard EN 17225-3 [35] and earning classification as "acceptable" according to Camps and Marcos [36]. However, these values were lower than the 1.08 to $1.2 \mathrm{~g} \mathrm{~cm}^{-3}$ of pine briquettes reported by de Souza and do Vale [37]. They were also lower than the $1.2 \mathrm{~g} \mathrm{~cm}^{-3}$ of briquettes produced with $10 \%$ moisture content and at a temperature of $73{ }^{\circ} \mathrm{C}$ reported by Nurek et al. [26]. Briquettes made from 100\% small particles (T3 (0:0:100)) were classified into class $A 1\left(\geq 1 \mathrm{~g} \mathrm{~cm}^{-3}\right)$, and all the rest were placed in class A2 $\left(\geq 0.9 \mathrm{~g} \mathrm{~cm}^{-3}\right)$. The values of particle density were consistent with those mentioned by Antwi-Boasiako and Acheampong [38], who reported that the pressure exerted on compaction with hydraulic piston machines, such as used in this work, reached densities lower than $1.00 \mathrm{~g} \mathrm{~cm}^{-3}$ because of limited pressure.

On the other hand, the highest density was achieved when 100\% small particles (T3 (0:0:100)) were used, which is consistent with the findings of Saptoadi [39], Nurek et al. [13], and Ndindeng et al. [40], who mentioned that the smaller the particle size, the lower the porosity and consequently the greater the density. In the same line, except for T6 (67:0:33), high percentages of small and medium particles, such as in mixtures T0 (12:71:17) (control), T2 (0:100:0), T4 (33:33:33), T8 (0:33:67), and T7 (0:67:33), produce briquettes with particle densities higher than $0.97 \mathrm{~g} \mathrm{~cm}^{-3}$. According to Kers et al. [12], small particle size yields better physical properties for briquettes, and Bello and Onilude [41] have stated that a sufficient amount of small particles is necessary for embedding into the larger particles to produce desirable characteristics for briquettes. The observed effect can be attributed to the fact that the high pressure caused by external force causes an increase in the area of contact between the particles, making the molecular forces high enough and increasing the adhesion force between the particles [42]. A contrary effect was seen with a high percentage of large particles, as in T1 (100:0:0), or large particles plus medium particles, as in mixtures T5 (67:33:00), T9 (33:67:00), and T10 (33:0:67), where low particle density values $\left(\leq 0.96 \mathrm{~g} \mathrm{~cm}^{-3}\right)$ were produced. As was shown by the response surface and contour graphs (Figure 4), briquettes with a density higher than $1 \mathrm{~g} \mathrm{~cm}^{-3}$ are produced when 
small particles in the mix are $100 \%$; however to obtain higher values than $0.98 \mathrm{~g} \mathrm{~cm}^{-3}$, the optimal mixture is achieved when the percentage of large particles is in the range $40-60 \%$, medium particles are in the range $10-40 \%$, and small particles are in the range $10-50 \%$.

\subsection{Volumetric Swelling}

The volumetric swelling of briquettes from all mixtures was found to be below the range of 15 to $20 \%$ recommended by Maradiaga et al. [29]. Despite the relatively high humidity to which the briquettes were subjected in the conditioned room, briquettes with lower percentages of volumetric swelling than reported by Ramírez-Ramírez et al. [43] were found, and also maintained a firm consistency. Swelling values lower than $3 \%$ were observed with high proportions of large particles mixed with any or smaller proportions of medium and small particles, such as in the T10 (33:0:67), T1 (100:0:0), T0 (12:71:17), T9 (33:67:0), T4 (33:33:0), T6 (67:0:33), and T5 (67:33:0) mixtures. This was similar to the result reported by Mendoza-Martinez et al. [44] when large particles added to any mixture of coffee-pine wood residues yielded a consistent decrease in volumetric swelling. Volumetric swelling higher than $3 \%$ was observed in mixtures T3, (0:0:100), T8 (0:33:67), T2 (0:100:0), and T7 (0:67:33) when the percentage of large particles was $0 \%$. Similar behaviors were reported by Saptoadi [39], who showed that briquettes with the least expansion were made with smaller particles. According to the response surface and contour graphs (Figure 5), the lowest volumetric swelling $(>1 \%)$ was found when the percentage of small particle sizes approached $0-10 \%$, large particles were from 60 to $70 \%$ and medium particles were from $30 \%$ to $50 \%$.

\subsection{Compression Resistance}

Compression resistance values ranged from 18.45 to $37.85 \mathrm{~N} \mathrm{~mm}^{-1}$, similar to the range 17.09-41.85 $\mathrm{N} \mathrm{mm}^{-1}$ reported by Mitchual et al. [24] when briquettes were produced from mixtures of Ceiba pentandra sawdust and oil palm mesocarp fibers. On the other hand, values were above those reported by Huko et al. [23] in briquettes made from mango seed shells and cashew shells. This is probably because they used bigger particle sizes ( 3 to $11 \mathrm{~mm}$ ), although, as the present research confirms, the smaller particle size, the higher the compression resistance values. Plíštil et al. [45] noted that improving the strength of briquettes during pressing is based on the presumption that high density produced during the pressing allows efficient compaction.

All treatments showed higher compression resistance values than treatment T1 $(100 \%$ large particles). The same relationship between large proportions of small particle fractions and compression resistance was presented by Nurek et al. [13] when $100 \%$ of the particles used were smaller than $1 \mathrm{~mm}$. These authors also found high compaction values when the two smallest fractions ( $\mathrm{f} 1<1 \mathrm{~mm}$ and $\mathrm{f} 2$ from 1 to $4 \mathrm{~mm}$ ) were used in proportions of $75 \%$ to $25 \%$, respectively. Mitchual et al. [46] reported a relationship between compression values and the proportion of large particles different from that observed here, assuming that compression resistance increased with larger particle sizes. They attributed this to the production of briquettes at low temperature, such that the formation of a solid bridge resulting from natural bonding of the chemical materials may be minimal or absent. Therefore, the main factors that contributed to the bond formed during this densification could have been the mechanical interlocking of biomass fibers and the adhesive force between the particles.

Compression resistance is one of the most important properties in the evaluation of the quality of briquettes, as it indicates the stacking capacity and impact caused by friction during transport, which can cause abrasion and crumbling [47]. According to the response surface and contour graphs (Figure 6), the highest compression resistance values (34 N $\mathrm{mm}^{-1}$ ) were found when the percentage of small particle sizes approached $100 \%$, and large and small particles ranged from 0 to $5 \%$. However, high resistance compression values $\left(>30 \mathrm{~N} \mathrm{~mm}^{-1}\right.$ ) also were found when the percentage of small particles ranged from 30 to $40 \%$, medium particles 5 to $30 \%$, and large particles 40 to $60 \%$. 


\subsection{Impact Resistance Index (IRI)}

The IRI values of the briquettes higher than $100 \%$ were found in treatments T7 (0:67:33) and T2 (0:100:0), where no large sawdust particles were used; values higher than $90 \%$ were found in treatments T3 (0:0:100), T4 (33:33:33), and T9 (33:67:0). Values for the treatments T8 (0:33:67), T0(12:71:17) (control), and T6 (67:0:33) were higher than 76.5\%, which, according to Melin [48], is the minimum requirement established by the Wood Pellet Association of Canada. The hardness results were based on briquettes produced by mechanical piston presses and screw presses, and hard enough to be transported in trucks over considerable distances without degrading [38].

The impact resistance of the briquettes showed an inverse relationship to the size of the particles, as the briquettes with smaller particles have a larger surface area, which increases shock absorption at the drop and improves bonding, similarly to the behavior presented by Huko et al. [23] and Nurek et al. [13]. The main factors that contribute to the formation of a stronger bond between particles during densification may be the mechanical interlocking and the adhesive force between biomass particles. However, it is often difficult to provide an acceptable result with this index because the ratio of test results and reality has not been thoroughly studied [38]. According to the response surface and contour graphs (Figure 7), the highest impact resistance values $(>100 \%)$ were obtained with mixtures containing percentages of medium particles approaching $100 \%$ and large and small particles approaching $0 \%$, while decreasing the percentages of medium particles from 100 to $70 \%$ and increasing the percentages of both large (0-5\%) and small (0-30\%) particles reduced the impact resistance values by up to $90 \%$.

\subsection{Gross Calorific Value}

The calorific power values of all treatments were similar to those reported by Sette et al. [47] for Eucalyptus wood (19.5 MJ kg ${ }^{-1}$ ) and higher than those reported by DíasArtigas et al. [9] (17.5 MJ kg-1), but lower than those reported by Carrillo-Parra et al. [49] (17.35-19,774 MJ kg ${ }^{-1}$ ) from briquettes made with fresh and weathered pine sawdust.

The values of calorific power for all treatments were higher than $15.5 \mathrm{MJ} \mathrm{kg}^{-1}$ established in EN 17225-3 [35], and all briquettes were classified as class A1. The large particle size was suited for the production of briquettes with high calorific power values, as was shown in treatment T1 (100:0:0). Mixtures with large and medium particle size percentages, such as T9 (33:67:0) and T5 (67:33:0), presented calorific power values higher than those obtained with mixtures containing higher proportions of small particles, as in T3 (0:0:100), T6 (67:0:33), and T8 (0:33:67). Zakari et al. [50] obtained similar results by studying the effects of particle size and the addition of binder on calorific values in briquettes, showing that small particles $(1.75 \mathrm{~mm}$ and $2.00 \mathrm{~mm}$ ) had the lowest calorific values, while the larger size of $3.35 \mathrm{~mm}$ had high calorific values.

Similar calorific power values in briquettes made with palm kernel shell were reported by Oke et al. [51]; when they increased the particle size, the calorific value increased. This may be because there is more space and consequently more air between larger particles, which makes the combustion process more efficient, producing higher calorific power.

According to the response surface and contour graphs (Figure 8), the highest gross calorific values $\left(>21 \mathrm{MJ} \mathrm{Kg}^{-1}\right.$ ) are yielded when the percentage of large particle sizes is from 95 to $100 \%$, and medium and small particles are from 0 to $5 \%$. The same gross calorific values ( $>21 \mathrm{MJ} \mathrm{Kg}^{-1}$ ) are obtained when the percentage of large particles is from 30 to $35 \%$ and the percentages of medium and small particles are from 65 to $70 \%$ and 0 to $5 \%$, respectively.

\section{Conclusions}

Mixtures of Pinus durangensis sawdust residues with different particle sizes affected particle density, volumetric swelling, compressive and impact resistance, and the calorific value of the briquettes. 
The values of particle density and compressive strength increased with the addition of small particle sizes to the mixtures, contrary to the IRI and volumetric swelling values, in which no trend was observed. On the other hand, the gross calorific values were acceptable for classification as quality biofuels. Employing the response surface methodology, the optimal ratios for large, medium, and small particle sizes used in briquette mixtures were found to be 0:0:100 for particle density, 65:35:0 for volumetric swelling, 0:0:100 for impact resistance, 0:100:0 for compression resistance, and 100:0:0 for gross calorific value.

Although the control treatment had acceptable values and its use is recommended for the manufacture of briquettes, it is important to mention that the particle size will be affected by different types of sawmill equipment and by the characteristics of the biomass. Therefore, investigations using different types of residual biomass obtained from different sawmill machinery are recommended.

Author Contributions: Conceptualization, A.C.-P. and J.R.G.-T.; methodology, A.C.-P., J.R.G.-T., C.P.-M., C.O.Z.-C., and O.M.-A.; validation, A.C.-P. and V.D.N.-R.; formal analysis, A.C.-P., J.R.G.-T., C.O.Z.-C., M.N.H., and O.M.-A.; investigation, C.O.Z.-C.; resources, A.C.-P.; writing-original draft preparation, A.C.-P. and V.D.N.-R.; writing-review and editing, J.R.G.-T., C.P.-M., C.O.Z.-C., M.N.H., and O.M.-A.; funding acquisition, A.C.-P. All authors have read and agreed to the published version of the manuscript.

Funding: This research was funded by the Energy Sustainability Fund through the project SENER CONACYT 2014 (No 246911): Cluster of Solid Biofuels for Thermal and Electric Generation. The funders had no role in the study design, data collection and analysis, decision to publish, or preparation of the manuscript.

Institutional Review Board Statement: Not applicable.

Informed Consent Statement: Not applicable.

Acknowledgments: We thank SENER-CONACYT for funding "Fondo de Sustentabilidad Energética", grant number SENER-CONACYT 2014246911 "Clúster de Biocombustibles Sólidos para la generación térmica y eléctrica" and CONACYT project 166444. This work is also part of the IBEROMASA Network (719RT0586) of the Ibero-American Program of Science and Technology for Development (CYTED).

Conflicts of Interest: The authors declare no conflict of interest.

\section{References}

1. Fregoso-Madueño, J.N.; Goche-Télles, J.R.; Rutiaga-Quiñones, J.G.; González-Laredo, R.F.; Bocanegra-Salazar, M.; ChávezSimental, J.A. Alternative uses of sawmill industry waste. Rev. Chapingo Ser. Ciencias For. Ambient. 2017, 23, 243-260. [CrossRef]

2. Ayala-Mendivil, N.; Sandoval, G. Bioenergía a partir de residuos forestales y de madera. Madera y Bosques 2018, 24, 1-14. [CrossRef]

3. SEMARNAT. Anuario Estadístico de la Producción Forestal; SEMARNAT: Mexico City, Mexico, 2016.

4. Villela-Suárez, J.M.; Aguirre-Calderón, O.A.; Treviño-Garza, E.J.; Vargas-Larreta, B. Availability of forest residues and potential for energy production in temperate forests in El Salto, Durango. Madera Bosques 2018, 24, 1-18. [CrossRef]

5. Cruz-Contreras, C. Residuos Generados del Aprovechamiento Maderable en el Estado de Durango. Bachelor's Thesis, Universidad Autónoma de Chapingo, Texcoco, Mexico, 2012.

6. Nájera-Luna, J.A.; Adame-Villanueva, G.H.; Méndez-González, J.; Vargas-Larreta, B.; Cruz-Cobos, F.; Hernández, F.J.; AguirreCalderón, C.G. Rendimiento de la madera aserrada en dos aserraderos privados de El Salto, Durango, México. Investig. Cienc. 2012, 20, 11-23.

7. Arroyo-Vinueza, J.S.; Reina-Guzmán, W.S. Aprovechamiento del recurso biomasa a partir de los desechos de madera para una caldera de vapor. Ingenius. Rev. Cien. Tec. 2016, 16, 20-29. [CrossRef]

8. Gwenzi, W.; Ncube, R.S.; Rukuni, T. Development, properties and potential applications of high-energy fuel briquettes incorporating coal dust, biowastes and post-consumer plastics. SN Appl. Sci. 2020, 2, 1-14. [CrossRef]

9. Díaz-Artigas, I.J.; Díaz-Concepción, A.; Rodríguez-Piñero, A.J.; Alfonso-Álvarez, A.; Tamayo-Mendoza, J.E. Briquetas energeticas con aserrín y corteza de pino. Ing. Energética 2020, 41, 1-6.10.

10. Chaloupková, V.; Ivanova, T.; Ekrt, O.; Kabutey, A.; Herák, D. Determination of particle size and distribution through image-based macroscopic analysis of the structure of biomass briquettes. Energies 2018, 11, 331. [CrossRef]

11. Brožek, M. The effect of moisture of the raw materialon the properties briquettes for energy use. Acta Univ. Agric. Silvic. Mendelianae Brun. 2016, 64, 1453-1458. [CrossRef] 
12. Kers, J.; Kulu, P.; Aruniit, A.; Laurmaa, V.; Križan, P.; Šooš, L.; Kask, Ü. Determination of physical, mechanical and burnig characteristics of polymeric waste material briquettes. Est. J. Eng. 2010, 16, 307-316. [CrossRef]

13. Nurek, T.; Gendek, A.; Roman, K.; Dabrowska, M. The impact of fractional composition of the mechanical properties of agglomerated logging residues. Sustainability 2020, 12, 6120. [CrossRef]

14. Maharani, R.; Yutaka, T.; Yajima, T.; Minoru, T. Scrutiny on physical properties of sawdust from tropical commercial wood species: Effects of different mills and sawdust's particle size. Indones. J. For. Res. 2010, 7, 20-32. [CrossRef]

15. Tumuluru, J.S.; Fillerup, E. Briquetting characteristics of woody and herbaceous biomass blends: Impact on physical properties, chemical composition, and calorific value. Biofuels Bioprod. Biorefining 2020, 14, 1105-1124. [CrossRef]

16. Berastegui-Barranco, C.; Ortega-Rodríguez, J. Elaboración de biocombustibles sólidos densificados a partir de tres biomasas residuales, tres tipos de bioaglomerante y carbón mineral del departamento de Córdoba. Ingeniare. Rev. Chil. Ing. 2017, 25, 643-653. [CrossRef]

17. Gutiérrez-Pulido, H.; de la Vara-Salazar, R. Análisis y diseño de experimentos, 2nd ed.; Mc Graw Hill/Interamericana Editores S.A. de C.V.: Mexico City, Mexico, 2008.

18. Niño, A.; Arzola, N.; Araque, O. Experimental study on the mechanical properties of biomass briquettes from a mixture of rice husk and pine sawdust. Energies 2020,13, 1060. [CrossRef]

19. Tumuluru, J.S.; Tabil, L.G.; Song, Y.; Iroba, K.L.; Meda, V. Impact of process conditions on the density and durability of wheat, oat, canola, and barley straw briquettes. Bioenerg. Res. 2015, 8, 388-401. [CrossRef]

20. Križan, P.; Svátek, M.; Matúš, M.; Beniak, J.; Lisý, M. Determination of compacting pressure and pressing temperature impact on biomass briquettes density and their mutual interactions. In Proceedings of the 14th International Multidisciplinary Scientific GeoConference SGEM 2014, Albena, Bulgaria, 19-25 June 2014.

21. Lela, B.; Barišić, M.; Nižetić, S. Cardboard/sawdust briquettes as biomass fuel: Physical-mechanical and thermal characteristics. Waste Manag. 2015, 47, 236-245. [CrossRef]

22. Liu, H.; Liu, G.; Li, L.; Liu, Y.; Peng, S.; Hu, D.; Dong, Z. Optimization of the manufacturing process of Pinus rigida briquette by response surface methodology. J. For. Eng. 2016, 1, 93-99.

23. Huko, D.; Kamau, D.N.; Ogola, W.O. Effects of varying particle size on mechanical and combustion characteristics of mango seed shell cashew nut shell composite briquettes. Int. J. Eng. Sci. Invent. 2015, 4, 32-39.

24. Mitchual, S.J.; Katamani, P.; Afrifa, K.A. Fuel characteristics of binder free briquettes made at room temperature from blends of oil palm mesocarp fibre and Ceiba pentandra. Biomass Convers. Biorefinery 2019, 9, 541-551. [CrossRef]

25. Nurek, T.; Gendek, A.; Roman, K. Forest residues as a renewable source of energy: Elemental composition and physical properties. BioRes 2018, 14, 6-20. [CrossRef]

26. Nurek, T.; Gendek, A.; Roman, K.; Dabrowska, M. The effect of temperature and moisture on the chosen parameters of briquettes made of shredded logging residues. Biomass and Bioenergy 2019, 130, 105368. [CrossRef]

27. Ortíz-Torres, L. Producción de Biocombustibles Sólidos de Alta Densidad en España; Boletín del CIDEU; Universidad de Vigo: Vigo, Spain, 2008.

28. UNE-EN 17827-2. Biocombustibles Sólidos. Determinación de la Distribución de Tamaño de Partícula para Combustibles sin Comprimir Parte:2 Método del Tamiz Vibratorio con Abertura de Malla Inferior o Igual a 3.15 mm; Asociación Española de Normalización y Certificación (AENOR): Madrid, Spain, 2016.

29. Maradiaga-Rodriguez, W.D.; Evangelista, A.W.; Sette, C.R.; Alves-Júnior, J.; Fernández da Silva, M. Producción de briquetas con residuos de cáscara de piñón manso (Jatropha curcas) y bagazo de caña de azúcar. Bosque 2017, 38, 527-533. [CrossRef]

30. Borowski, G.; Hycnar, J.J. Utilization of fine coal waste as a fuel briquettes. Int. J. Coal Prep. Util. 2013, 33, 194-204. [CrossRef]

31. ASTM D143-83. Standard Methods of Testing Small Clear Specimens of Timber; American Society of Testing Material (ASTM): West Conshohocken, PA, USA, 1994.

32. ASTM D440-86. Standard Test Method of Drop Shatter Test for Coal; American Society of Testing Material (ASTM): West Conshohocken, PA, USA, 1998.

33. Richards, S.R. Physical testingof fuel briquettes. Fuel 1990, 25, 89-100. [CrossRef]

34. UNE-EN 14918. Biocombustibles Sólidos. Determinación del Poder Calorífico; Asociación Española de Normalización y Certificación (AENOR): Madrid, Spain, 2011.

35. UNE-EN 17225-3. Biocombustibles Sólidos. Especificaciones y Clases de Combustibles. Parte 3: Clases de Briquetas de Madera; Asociación Española de Normalización y Certificación (AENOR): Madrid, Spain, 2014.

36. Camps, M.M.; Marcos, M.F. Los Biocombustibles, 2nd ed.; Mundi-Prensa Libros: Madrid, Spain, 2008.

37. de Souza, F.; do Vale, A.T. Energy density of lignocellulosic biomass briquettes and its relationship with briquetting parameters. Pesqui. Florest. Bras. 2016, 36, 405-413. [CrossRef]

38. Antwi-Boasiako, C.; Acheampong, B.B. Strength properties and calorific values of sawdust-briquettes as wood-residue energy generation source from tropical hardwoods of different densities. Biomass Bioenergy 2016, 85, 144-152. [CrossRef]

39. Saptoadi, H. The best biobriquette dimension and its particle size. Asian J. Energy Environ. 2008, 9, $161-175$.

40. Ndindeng, S.A.; Mbassi, J.E.G.; Mbacham, W.F.; Manful, J.; Graham-Acquaah, S.; Moreira, J.; Dossou, J.; Futakuchi, K. Quality optimization in briquettes made from rice milling by-products. Energy Sustain. Dev. 2015, 29, 24-31. [CrossRef]

41. Bello, R.S.; Onilude, M.A. Physico-mechanical characteristics of high density briquettes produced from composite sawdust. J. Appl. Sci. Environ. Manag. 2020, 24, 779-787. [CrossRef] 
42. Huanca-Ríos, L.V. Evaluación del proceso de producción de briquetas a partir de residuos de dos maderas de la zona de Iquitos, Loreto. Bachelor's Thesis, Forest Engineering, Universidad Nacional Agraria La Molina, Lima, Peru, 2017.

43. Ramírez-Ramírez, M.A.; Carrillo-Parra, A.; Ruíz-Aquino, F.; Pintor-Ibarra, L.F.; González-Ortega, N.; Orihuela-Equihua, R.; Carrillo-Ávila, N.; Luján-Álvarez, C.; Rutiaga-Quinones, J.G. Valorization of briquettes fuel using Pinus spp. sawdust from five regions of Mexico. BioResources 2021, 16, 2249-2263. [CrossRef]

44. Mendoza-Martinez, C.L.; Sermyagina, E.; de Cassia-Oliveira, C.A.; Vakkilainen, E.; Cardoso, M. Production and characterization of coffee-pine wood residue briquettes as an alternative fuel for local firing systems in Brazil. Biomass Bioenergy 2019, 123, 70-77. [CrossRef]

45. Plíštil, D.; Brožek, M.; Malaták, J.; Roy, A.; Hutla, P. Mechanical characteristics of standard fuel briquettes on biomass basis. Res. Agric. Eng. 2005, 51, 66-72. [CrossRef]

46. Mitchual, S.J.; Frimpong-Mensah, K.; Darkwa, N.A. Effect of species, particle size and compacting pressure on relaxed density and compressive strength of fuel briquettes. Int. J. Energy Environ. Eng. 2013, 4, 1-6. [CrossRef]

47. Sette, C.R., Jr.; Santiago Hansted, A.L.; Novaes, E.; Fonseca e Lima, P.A.; Rodrigues, A.C.; Rodrigues de Souza Santos, D.; Minoru Yamaji, F. Energy enhancement of the eucalyptus bark by briquette production. Ind. Crop. Prod. 2018, 122, 209-213. [CrossRef]

48. Melin, S. Quality Certification and Standards for Solid Biofuels; Wood Pellet Association of Canada: Revelstoke, BC, Canada, 2011.

49. Carrilo-Parra, A.; Contreras- Ortiz, E.; Garza-Ocañas, F.; Ngangyo-Heya, M.; Rutiaga-Quiñones, J.G. Efecto de la intemperización y proceso en las características físicas, mecánicas y energéticas de briquetas. Rev. Mex. Ciencias For. 2018, 9, 496-513. [CrossRef]

50. Zakari, I.Y.; Ismalia, A.; Sadiq, U.; Nasiru, R. Investigation on the effects of addition of binder and particle size on the high calorific value of solid biofuel briquettes. J. Nat. Sci. Res. 2013, 3, 30-35.

51. Oke, P.K.; Olugbade, T.O.; Olaiya, G.N. Analysis of the effect of varying palm kernel particle sizes on the calorific value of palm kernel briquette. Br. J. Appl. Sci. Technol. 2016, 14, 1-5. [CrossRef] 